Revue belge de géographie

\title{
Bernie-Boissard C., Regards d'urbanité, parcours, recherches et pistes dans la ville
}

Paris, L'Harmattan, 2004, 346 p.

\section{Julien Vandeburie}

\section{(2) OpenEdition}

\section{Journals}

Édition électronique

URL : http://journals.openedition.org/belgeo/12216

DOI : $10.4000 /$ belgeo.12216

ISSN : 2294-9135

Éditeur :

National Committee of Geography of Belgium, Société Royale Belge de Géographie

Édition imprimée

Date de publication : 31 décembre 2005

Pagination : 518-519

ISSN : 1377-2368

Référence électronique

Julien Vandeburie, "Bernie-Boissard C., Regards d'urbanité, parcours, recherches et pistes dans la ville», Belgeo [En ligne], 4 | 2005, mis en ligne le 29 octobre 2013, consulté le 22 septembre 2020. URL : http://journals.openedition.org/belgeo/12216; DOI : https://doi.org/10.4000/belgeo.12216

Ce document a été généré automatiquement le 22 septembre 2020.

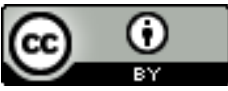

Belgeo est mis à disposition selon les termes de la licence Creative Commons Attribution 4.0 International. 


\section{Bernie-Boissard C., Regards d'urbanité, parcours, recherches et pistes dans la ville}

Paris, L'Harmattan, 2004, 346 p.

Julien Vandeburie

\section{RÉFÉRENCE}

Bernie-Boissard C., Regards d'urbanité, parcours, recherches et pistes dans la ville, Paris, L'Harmattan, 346 p.

1 L'auteur commence son ouvrage en affirmant que la ville est d'abord pour elle une pratique. Que l'approche du terrain est fondamentale et elle le montrera ensuite par exemple en essayant de répondre à des questions telles que : « La ville est-elle toujours la demeure de l'homme? » mais aussi « la ville comme espace de la politique, et en tant que politique de l'espace $»$.

2 La première partie, Parcours, nous entraîne dans Mourenx, Bordeaux et Nîmes. De nombreuses questions sont traitées mais relevons entre autres celle de la citoyenneté et des espaces de pouvoir.

3 La deuxième partie, Recherches, détaille la ville comme une maison. Fondations: l'identité urbaine; entrée: la production de la ville; façade: le discours et les représentations; étage noble : le gouvernement local ; cour et jardin : le temps vécu dans la ville. Ville probable, ville improbable : l'auteur traite son sujet sous des angles multiples.

4 La troisième partie, Pistes, est divisée en trois chapitres: méthodes et déclinaisons enseignantes, itinéraires et perspectives, ouvertures. On revient là sur les terrains bien connus de l'auteur, particulièrement l'exemple nîmois. La dernière partie rassemble des cas d'études et des articles, surtout sur Nîmes. 
5 Au final, un ouvrage surtout intéressant pour ses seconde et troisième parties qui nous interpellent davantage. 